\title{
THIS IS THE FEELING THAT BREAKS
}

This is the feeling that breaks the ends of your words; the wind that blows an already hard rain into your face. You look down at the ground, but it is not going to assist you. It feels itself under attack, betrayed by the explorer's shoes, the road that followed him in, the house built at the end of the road. A door opens, and light falls onto the ground; what disturbs your sleep in the same way? Now the deer have a drum they play only at night, to warn the earth of their arrival. Everyone in the world hears that drum, out of one ear, the sound growing dimmer and dimmer. There are more footsteps and more trees losing their leaves in the middle of spring. There are feelings that cause you to put your hands over your eyes, that lead the usually immobile branches to slap at your ankles and wrists. Your only defense is that you are defenseless; that you have come out into the open expecting some open to be there. 